\title{
SMALL VOLUME HYPERTONIC RESUSCITATION OF CIRCULATORY SHOCK
}

\author{
Mauricio Rocha-e-Silva and Luiz F. Poli de Figueiredo
}

ROCHA-E-SILVA et al. Small volume hypertonic resuscitation of circulatory shock. CLINICS 60(2):159-172, 2005.

Small volume hypertonic resuscitation is a relatively new conceptual approach to shock therapy. It was originally based on the idea that a relatively large blood volume expansion could be obtained by administering a relatively small volume of fluid, taking advantage of osmosis. It was soon realized that the physiological vasodilator property of hypertonicity was a useful byproduct of small volume resuscitation in that it induced reperfusion of previously ischemic territories, even though such an effect encroached upon the malefic effects of the ischemia-reperfusion process. Subsequent research disclosed a number of previously unsuspected properties of hypertonic resuscitation, amongst them the correction of endothelial and red cell edema with significant consequences in terms of capillary blood flow. A whole set of actions of hypertonicity upon the immune system are being gradually uncovered, but the full implication of these observations with regard to the clinical scenario are still under study. Small volume resuscitation for shock is in current clinical use in some parts of the world, in spite of objections raised concerning its safety under conditions of uncontrolled bleeding. These objections stem mainly from experimental studies, but there are few signs that they may be of real clinical significance. This review attempts to cover the earlier and the more recent developments in this field.

KEYWORDS: Shock therapy. Hemorrhage. Hypertonic saline. Immune circulation.

Hypertonic salt solutions (HS) have been viewed with interest as possible therapeutic agents for hemorrhage since 1917, when Penfield published a report showing that a relatively small volume of $1.8 \% \mathrm{NaCl}$ induced a transient recovery of the hypotension caused by blood loss in $\operatorname{dog} \mathrm{s}^{1}$. Later, a $5 \% \mathrm{NaCl}$ solution was unsuccessfully tried for the treatment of Buerger's disease ${ }^{2}$. No other interesting data on this interaction appeared in press till the sixties, when Baue et al. and Messmer et al. reported equally transient effects of $5 \% \mathrm{NaCl}$ and $7.5 \% \mathrm{NaHCO}_{3}$ in severely hemorrhaged $\operatorname{dogs}^{3-5}$. Gazitua et al. demonstrated that hyperosmotic $\mathrm{NaCl}$ solutions induced vasodilation when selectively infused in the renal, coronary, and limb circulations ${ }^{6}$.

However, interest for the use of hypertonic solutions for the treatment of shock was enhanced when we showed that

Division of Applied Physiology, Heart Institute (InCor), Hospital das Clínicas, Faculty of Medicine, University of São Paulo - São Paulo/SP, Brazil.

E-mail: mrsilva@incor.usp.br

Received for publication on February 2, 2005.

Accepted for publication on March 2, 2005. severely hemorrhaged dogs $(40 \mathrm{ml} / \mathrm{kg}$ blood loss $)$ responded with a restored arterial pressure and cardiac output following IV bolus injections of $4 \mathrm{~mL} / \mathrm{kg}$ of $7.5 \% \mathrm{NaCl}$, a volume equivalent to only $10 \%$ of the volume of shed blood $^{7}$. Long term survival was observed in all $10 \mathrm{HS}$ treated dogs; in contrast, control animals, treated with an equal volume of isotonic saline, responded with neither hemodynamic improvement, nor survival.

In the same year, Fellippe et al. pioneered human studies: Hypertonic $\mathrm{NaCl}$ solutions $(7.5 \%$ in successive $50 \mathrm{ml}$ aliquots) given to patients in refractory shock at an emergency intensive care unit induced hemodynamic benefits. ${ }^{8}$ These reports stimulated hundreds of studies, including experimental and more than 60 clinical trials with $7.5 \% \mathrm{NaCl}$ in the treatment of several conditions, such as hemorrhagic, cardiogenic, and septic shock, as well as a volume supporting solution during major surgical procedures. ${ }^{9}$ Several groups confirmed our findings that a small volume of $7.5 \%$ $\mathrm{NaCl}$, infused to animals which had lost $40-50 \%$ of their blood volumes, rapidly restored arterial pressure, cardiac output and blood flows to vital organs. ${ }^{10-14}$ The hypertonic 
saline dextran (HSD) association, combining the hyperosmotic effects of $\mathrm{NaCl}$ to the hyperoncotic effects of dextran ${ }^{12}$ added new conceptual and practical possibilities. In this review we cover a number of significant aspects of the interaction of hypertonic solutions with severe hemorrhage and circulatory shock.

\section{PHYSICAL PROPERTIES OF HS AND HSD}

A simple physical interaction is mainly responsible for the initial effect of HS, namely a significant plasma volume expansion. The standard dose of HS ( $4 \mathrm{~mL} / \mathrm{kg}$ of $7.5 \%$ $\mathrm{NaCl}$ ) adds a load of $5.12 \mathrm{mEq} \mathrm{Na} / \mathrm{kg}$ body weight. In theory, if diluted exclusively into the plasma volume of a normovolemic animal $(40 \mathrm{~mL} / \mathrm{kg})$, this $\mathrm{Na}^{+}$load should increase plasma $\mathrm{Na}^{+}$to approximately $263-268 \mathrm{mEq} / \mathrm{L}(128$ $\mathrm{mEq} / \mathrm{l}$ above the basal level of $135-140 \mathrm{mEq} / \mathrm{L})$. However, such values are never observed in laboratory or clinical trials. Figure 1 shows the only way by which such a concentration may be achieved: the full $\mathrm{Na}^{+}$load $(5.12 \mathrm{mEq} / \mathrm{kg})$ must be administered intravenously over 10 seconds, and plasma $\mathrm{Na}^{+}$read immediately thereafter. Under these conditions plasma $\mathrm{Na}^{+}$effectively rose to $267 \mathrm{mEq} / 1$. Such a rapid injection is only feasible if we employ a saturated $30 \% \mathrm{NaCl}$ solution, thereby reducing the injected volume to $1 \mathrm{~mL} / \mathrm{kg}$. Figure 1 also shows that using the standard $7.5 \% \mathrm{NaCl} \mathrm{HS}$, the same $\mathrm{Na}^{+}$load can be injected within one minute: in this manner, it increases plasma $\mathrm{Na}^{+}$concentration by $25 \mathrm{mEq} / \mathrm{L}$, from 140 to $165 \mathrm{mEq} / \mathrm{L}$. The latter value is almost identical to that observed one minute after the ten second $30 \% \mathrm{NaCl}$ injection. The $25 \mathrm{mEq} / \mathrm{L}$

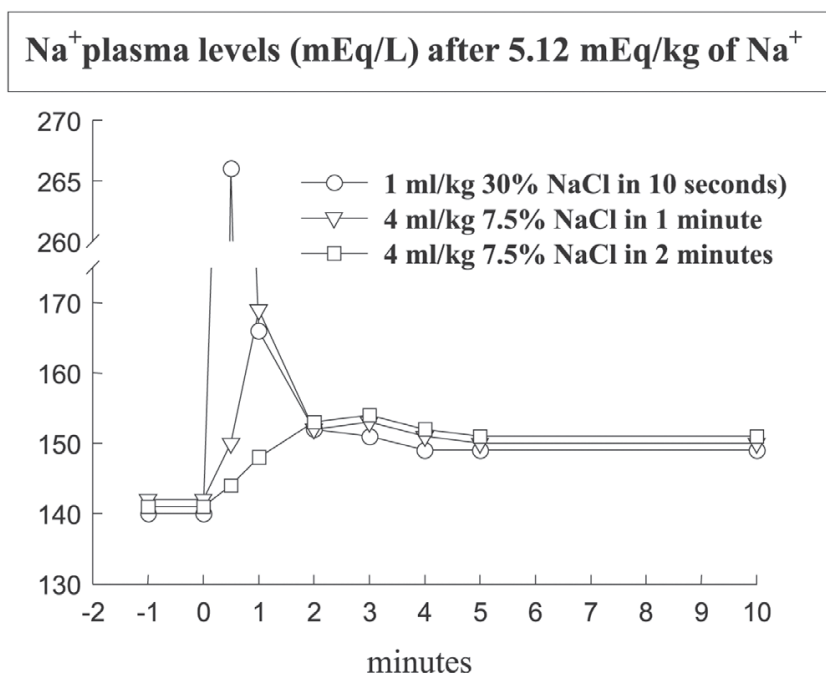

Figure 1 - Sodium plasma levels after intravenous injections of 5.12 $\mathrm{mEq} / \mathrm{kg}$ de $\mathrm{Na}^{+}$to normovolemic anesthetized dogs. This sodium load was infused in three different regiments: as $30 \% \mathrm{NaCl}$ in 10 seconds (in circles), as $7.5 \% \mathrm{NaCl}$ in one minute (in triangles), and as $7.5 \%$ $\mathrm{NaCl}$ in two minutes (in squares).
$\mathrm{Na}^{+}$increase is the correct theoretical value for the dilution of $5.12 \mathrm{mEq} / \mathrm{kg}$ across the entire extracellular space (approximately $200 \mathrm{ml} / \mathrm{kg}$ ). Finally, Figure 1 shows that when the $\mathrm{Na}^{+}$load is given over $2 \mathrm{~min}$, the observed $\mathrm{Na}^{+}$ peak is $152 \mathrm{mEq} / \mathrm{L}$. Again this value is almost identical to that obtained at 2 min following the ten seconds injection. More significantly, this is also the $\mathrm{Na}^{+}$peak value typically observed in experimental and clinical trials with $\mathrm{HS}^{15}$. It clearly demonstrates that the extravascular compartment has been expanded by HS, a fact which can only be accounted for by assuming that water has been osmotically drawn out of the intracellular compartment by HS. In summary, these three decay curves of $\mathrm{Na}^{+}$indicate that the theoretical distribution space is the intravascular compartment at zero time, the extracellular space at $1 \mathrm{~min}$. At $2 \mathrm{~min}$, the $\mathrm{Na}^{+}$decay from 165 to $152 \mathrm{mEq} / \mathrm{L}$ indicates that the extracellular compartment has been expanded by approximately $8 \%$ to $216 \mathrm{ml} / \mathrm{kg}$. These theoretical considerations apply to a normovolemic animal. In an oligovolemic animal, after severe bleeding, extracellular expansion would be theoretically greater. In our original paper, ${ }^{7}$ using plasma volume and hematocrit measurements after hypertonic resuscitation, we detected an initial increment in plasma volume of $11 \mathrm{~mL} / \mathrm{kg}$. This represents a $30 \%$ increase of pre-existing volumes, or about $2.75 \mathrm{~mL}$ of plasma for each $\mathrm{mL}$ of the injected solution. In contrast, standard isotonic solutions only induce an expansion of $0.33 \mathrm{~mL}$ for each $\mathrm{mL}$ injected, as a consequence of its distribution throughout the extra vascular compartment.

The association of $6 \%$ dextran-70 to the $7.5 \% \mathrm{NaCl}$ solution (HSD) introduced by Kramer et al., ${ }^{12}$ somewhat enhances the initial plasma expansion. However, it's most important effect is the maintenance of intravascular expansion for longer periods, thus prolonging the hemodynamic and metabolic benefits of the hypertonic solutions. ${ }^{11,12,16}$ Figure 2 shows plasma expansion produced by isotonic crystalloid, HS and HSD. The addition of HSD alters the dynamics of fluid shift by generating an extra oncotic gradient across the endothelial barrier. This further expands the intravascular compartment, but now at the expense of fluid moved from the interstitial space. The 6\% Dextran-70 solution exerts an oncotic pressure of $70 \mathrm{~mm} \mathrm{Hg}$, greater than that observed with a similar concentration of human albumin. Results described for HSD have also been demonstrated with $\mathrm{HSS}$, in which $6 \%$ hetastarch is added to the $7.5 \% \mathrm{NaCl}$ solution. ${ }^{17}$ Figure 3 summarizes the physical properties of HS and HSD. The respective reflection coefficients of the endothelial barrier and cellular membrane to $\mathrm{Na}^{+}$must be considered in the determination of the osmotic force generated by the gradients established after the use of hypertonic saline solution. The endothelial barrier reflection co- 
plasma volume expansion ( $\mathrm{ml}$ expansion/ml infused)

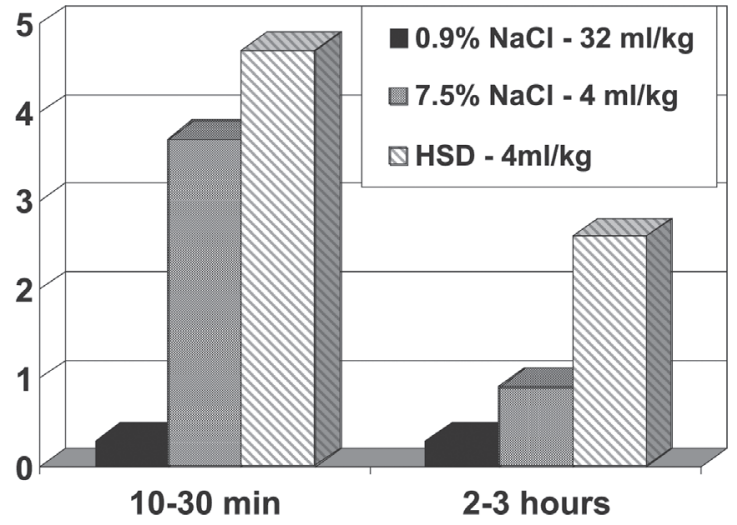

Figure 2 - Plasma volume expansion in $\mathrm{ml}$ expansion per $\mathrm{ml}$ infused after $32 \mathrm{ml} / \mathrm{kg}$ isotonic $\mathrm{NaCl}, 4 \mathrm{ml} / \mathrm{kg} 7.5 \% \mathrm{NaCl}$, or $4 \mathrm{ml} / \mathrm{kg} 7.5 \%$ NaCl-6\% Dextran-70.

efficient is 0.1 , while the cell membrane coefficient is 1 . Thus, for instance, a gradient of $25 \mathrm{mOsm} / \mathrm{L}$ exerts an osmotic pressure of $500 \mathrm{mmHg}$ across the cellular membrane, but only $50 \mathrm{mmHg}$ across the endothelial membrane. Equilibrium will be reached $1 \mathrm{~min}$ across the endothelial membrane, in 2 min across the cell membrane. Thus, the intravascular expansion induced by hypertonic resuscitation occurs from the intracellular compartment and not from the interstitial compartment, which is also expanded. This fluid shift from the intracellular to the extracellular compartment may be regarded as beneficial, since during shock states, ischemia-reperfusion, extracorporeal circulation and sepsis, among other conditions, there is cellular edema, due to the action of inflammatory mediators and because of sodium/potassium pump dysfunction in the cellular membranes. ${ }^{18}$ Figure 3 also shows how dextran en-

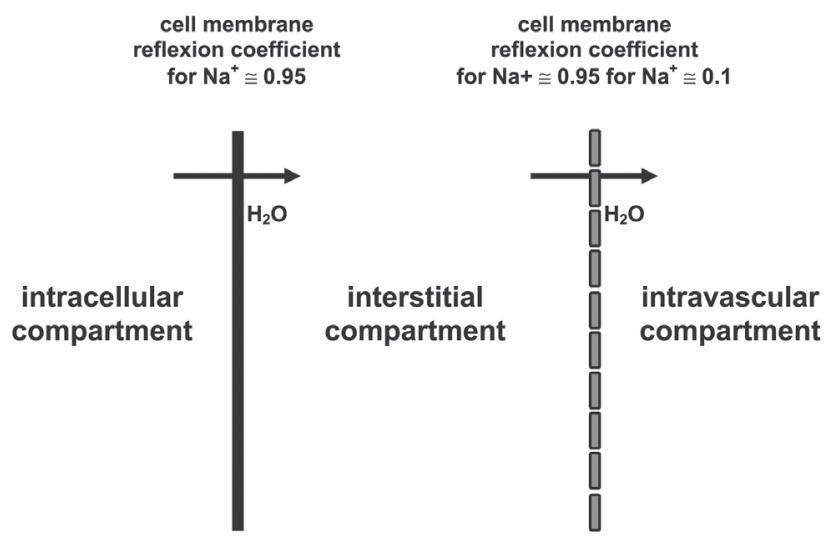

Figure 3 - Summary of physical properties of intravenously injected HS/HSD. Hypertonic $\mathrm{Na}^{+}$moves water osmotically across the cell membrane; hyperoncotic dextran or hetastarch moves water oncotically across the endothelial barrier. hances the water shift from the interstitial to the intravascular compartment.

\section{PHYSIOLOGICAL PROPERTIES OF HS/HSD}

When a $4 \mathrm{ml} / \mathrm{kg}$ of $2,400 \mathrm{mOsm} / \mathrm{L}$ sodium salt solution is administered to animal previously submitted to severe blood loss, a cardiovascular improvement consisting of partial recovery of mean arterial pressure and cardiac output is observed. It has been variously attributed to plasma volume expansion, vasodilatation in several vascular beds ${ }^{6}$ and to a direct cardiac inotropic effect. ${ }^{19,20}$ Renal and mesenteric vasodilation ${ }^{6,7}$ appear to be particularly important because hemorrhage induces critical flow restrictions to these territories.

Acid base equilibrium is also affected by HS. An initial enhancement of the metabolic acidosis induced by shock is generally observed and has been attributed to hyperchloremic acidosis. This is, however, followed by a recovery towards baseline levels, which has been attributed to a recovery of nutrient flow through previously constricted territories. ${ }^{1,20,21,22}$

Catecholamine and vasopressin release are also affected by the hemorrhage - HS/HSD interaction. Hemorrhage induces elevated levels of vasopressin and catecholamines; these effects are partially offset by resuscitation with HS/ HSD ${ }^{23}$ Some of these physiological responses to hypertonicity will be re-examined in the following paragraphs.

Effects of HS on the microcirculation. The classical papers of Mazzoni et al. ${ }^{24,25}$ demonstrated that the main sources for the observed plasma volume expansion after $7.5 \% \mathrm{NaCl}$ injection are the red blood cells and the endothelium, mainly on account of their immediate physical contact with the intravascular hypertonicity. These cell species, which had been made edematous by shock, lose $8 \%$ of their volumes directly to the intravascular compartment. Apart from the volume expansion, this fluid shift has important hemodynamic consequences, at the microcirculatory level. The hemorrhage induced edema of the endothelial and of the red blood cells are of critical importance in terms of capillary flow, where the ratio between the vascular lumen and red blood cell cross section approaches unity. Endothelial edema reduces the lumen and red cell edema increases red cell cross section, thereby increasing viscosity and hydraulic resistance. Under these circumstances, cellular edema compromises the microcirculatory blood flow. Small volume hypertonic resuscitation instantly corrects this geometric anomaly, whereas larger volume isotonic resuscitation will only correct this over a much more extended period, after the successful correction of oxygen supply..$^{24,25}$ 
These microcirculatory disturbances have been implicated in the origin of sepsis and multiple organ dysfunction that occur after an initially successful resuscitation of posttraumatic shock. ${ }^{26}$ The resulting sustained splanchnic vasoconstriction may cause gut mucosal ischemia and consequent compromise of its integrity, with the consequent predisposition to bacterial and toxin penetration from the intestinal lumen into the systemic circulation. Microcirculation in the gut mucosa may be even more severely compromised during the reperfusion period. This secondary effect, mediated by oxygen free radicals, also results in capillary lumen narrowing, leukocyte adhesion and activation, and stimulation of several inflammatory mediators and cytokines, which may cause local tissue and remote organ injuries. ${ }^{26-28}$

Under these conditions, hypertonic solutions may produce several beneficial effects through the rapid hemodynamic restoration at the macro and microcirculatory levels. Based on these observed effects in posttraumatic shock, studies with $7.5 \% \mathrm{NaCl}$ solutions, with and without dextran or hetastarch, have been performed using several models of sepsis and septic shock. Benefits have been observed at the level of global and regional hemodynamics. ${ }^{29-31}$

Effects of HS on the vascular resistance. The hypertonicity induced by the $7.5 \% \mathrm{NaCl}$ injection is responsible for the increased blood flow in the peripheral circulation and in the microcirculation as a consequence of a reduced vascular resistance, primarily by arteriolar vasodilatation. This response is caused by a direct relaxant effect of hypertonicity on vascular smooth muscle.

The reduction in blood viscosity, by the hemodilution rapidly induced by the hypertonic solution, also contributes to the reduction in vascular resistance. The use of $7.5 \%$ $\mathrm{NaCl}$ in shock produces vasodilatation and increased regional blood flow to coronary ${ }^{32}$, renal $^{6,33}$, intestinal ${ }^{14,19,34}$ and skeletal muscle ${ }^{14}$ circulations.

Effects of HS on myocardial contractility. The hemodynamic benefits observed after $7.5 \% \mathrm{NaCl}$ have been partially attributed to a direct cardiac inotropic effect induced by hypertonicity. ${ }^{35,36}$ However, an evaluation of left ventricular contractility after $7.2 \% \mathrm{NaCl} / 6 \%$ hetastarch in anesthetized, stable patients without cardiovascular disease, did not demonstrate any clinically relevant positive inotropic effect. All hemodynamic benefits were therefore attributed to the combination of volume expansion and decreased afterload. ${ }^{37}$

Some authors showed no direct inotropic effect with hypertonic solutions in the treatment of hemorrhagic shock, ${ }^{38}$ while others showed negative inotropic effects in normovolemic dogs. ${ }^{39}$ Thus, whether or not hypertonic so- lutions have a direct positive inotropic effect contributing to the hemodynamic benefits remains controversial.

Additional regional effects. Improvements in renal function have been observed after HSD infusion to animals in shock. This benefit is probably multifactorial, resulting from volume expansion, general hemodynamic improvement and increased renal blood flow. ${ }^{40}$

A great benefit with hypertonic resuscitation has been observed on cerebral hemodynamics during hemorrhagic shock, particularly in the presence of intracranial hypertension and systemic hypotension. ${ }^{41,42}$ The rapid restoration of the arterial pressure associated with a reduction in intracranial hypertension induced by hypertonic solutions suggests a potential clinical application of these solutions for trauma victims with head injury and associated lesions with hypotension, a subset of trauma victims with poor prognosis. ${ }^{43}$

In the clinical trials, patients with low Glasgow coma score and hypotension after trauma benefited from an initial infusion of hypertonic solutions. ${ }^{44}$

\section{IMMUNE AND INFLAMMATORY EFFECTS OF HS/ HSD}

The physical and physiological effects of small volume hypertonic resuscitation are essentially short term in duration, which contrasts with the long term survival produced by HS. The long-term effects of hypertonic resuscitation which shall now be discussed only began to be adequately evaluated in the last decade.

The role of the dextran component as a oxygen free radicals scavenger and the role of HSD as an inhibitor of leukocyte activation had already been recognized. ${ }^{45}$ More recently, a series of experiments have shown that hypertonic saline solution, even without dextran, significantly interferes with the immune responses, both in vitro and in vivo. ${ }^{46-57}$

The addition of hypertonic saline solution to a lymphocyte culture media, in concentrations similar to those obtained with systemic infusion of $4 \mathrm{~mL} / \mathrm{kg}$ of $7.5 \%$ $\mathrm{NaCl}$ in humans, determined a significant increase in lymphocyte proliferation. ${ }^{46}$ The addition of prostaglandin $\mathrm{E}_{2}\left(\mathrm{PGE}_{2}\right)$ to the culture media, in the absence of hypertonic saline, caused a reduction in T-cells proliferation, when compared to control cultures. On the other hand, when hypertonic saline was added to the culture media containing $\mathrm{PGE}_{2}$, there was a complete reversal on the $\mathrm{PGE}_{2}$-induced immunosupression. ${ }^{47,48}$

These in vitro findings were confirmed in vivo using a hemorrhagic shock model in mice, in which the infusion of $7.5 \% \mathrm{NaCl}$ reversed the cellular immune function depression that occurs after hemorrhage. Plasma levels of several cytokines were determined, and it was concluded that hyper- 
tonic saline solution prevents immunossupression probably by decreasing plasma levels of IL-4 and $\mathrm{PGE}_{2} \cdot{ }^{48} \mathrm{~A}$ double hit model in mice, hemorrhagic shock, followed by resuscitation then by cecal puncture 24 hours later, showed that $7.5 \% \mathrm{NaCl}$ resuscitation was associated to a significant decrease in mortality 72 hours after peritonitis induction, compared to conventional isotonic resuscitation. Moreover, a significant reduction in pulmonary and hepatic changes after hypertonic solutions was observed. ${ }^{49}$ Neutrophile activation after the trauma-hemorrhagic shock interaction is significantly limited by treatment with HS. ${ }^{50}$ Significant reductions have been detected in bacterial translocation and pulmonary lesions in rats with hemorrhagic shock which were treated with hypertonic saline solution. ${ }^{51}$ More recently it has been shown that polymorph nuclear rolling and sticking, as well as lung expression of ICAM 1, and leakage are inhibited by treating severe hemorrhage with HS. ${ }^{52,53}$ It has also be shown that hypertonic saline inhibits neutrophile priming via attenuation of p38 MAPK signaling. ${ }^{54}$ Inhibition of alveolar macrophage activation by prevention of the systemic oxidative stress due to gut ischemia/reperfusion has also been claimed..$^{55}$

A possible interaction between hypertonic saline for the treatment of hemorrhage, apoptosis, and tissue damage of the small intestine has also been recently suggested. ${ }^{57}$ In another study, we have shown that hypertonic saline may exert its long-term benefits after hemorrhagic shock by modulating bone marrow apoptosis. ${ }^{58}$, a mechanism that has been linked to sepsis and multiple organ dysfunctions. ${ }^{59}$

Hypertonic saline resuscitation may also influence the transcriptional, functional and protein expression of genes related to Matrix metalloproteinases (MMPs) and their specific physiological inhibitors, tissue inhibitors of metalloproteinases (TIMPs), which are thought to play an essential role in tissue repair, cell death and morphogenesis. ${ }^{60}$

Based on these evidences, it has been suggested that resuscitation with hypertonic saline solutions present significant potential as an immunomodulator agent for trauma victims. ${ }^{61}$ Hypertonic saline induced systemic, regional and immunomodullatory beneficial effects were recommended for the potential use as treatment of septic shock. ${ }^{62,63}$. However, all this evidence requires additional research and careful evaluation in clinical trials using these solutions. A recent review by Kolsen-Petersen suggests that many of the effects described in animal models may be inapplicable to the clinical scenario. ${ }^{64}$

\section{ASSOCIATION WITH OXYGEN CARRIERS}

There is a great interest in the association of hypertonic saline, which causes hemodilution with oxygen carriers, particularly modified cell-free hemoglobins, which are currently undergoing phase III clinical trials. It has been well demonstrated that small volumes of these solutions restore arterial pressure in animals in hemorrhagic shock. However, this benefit is achieved through marked vasoconstriction secondary to nitric oxide scavenging by the free hemoglobin.

Severe pulmonary hypertension and coronary, splanchnic and renal vasoconstriction have been also attributed to cell-free hemoglobin solutions. ${ }^{65-68}$ The association of hypertonic sodium acetate solution, $2400 \mathrm{mOsm} / \mathrm{L}$, with cell-free hemoglobin limited the potent arteriolar vasodilator properties of this variety of hypertonic solution, because of the marked hemoglobin-induced vasoconstriction. With this combination, it has been shown that the association of peripheral vasodilatation, induced by the hypertonic solution, with the pulmonary hypertension, induced by the hemoglobin, may result in severe hemodynamic stability. ${ }^{67}$ Slower infusions of the combined hypertonic-hemoglobin solution, the use of inhaled nitric oxide to selectively reverse pulmonary hypertension, ${ }^{68}$ and the use of encapsulated hemoglobin, ${ }^{69}$ which is definitely less vasoconstrictive, are some of the potential alternatives that have been tested to expand the benefits of hypertonic saline resuscitation for the next years.

\section{CLINICAL EXPERIENCE AND PERSPECTIVES}

A substantial clinical experience has accumulated regarding the use of $7.5 \% \mathrm{NaCl}$ solutions. ${ }^{17}$ Such studies have provided valuable insights regarding safety and efficacy of hypertonic saline solutions. A majority of patients received these solutions as the initial treatment for posttraumatic hypotension followed by standard-of-care isotonic crystalloid solutions, both in pre-hospital or in the emergency room environment, including several prospective and doubleblind studies. ${ }^{70-78}$

These patients have been submitted to extensive clinical and laboratory evaluation, demonstrating the highly desirable safety profile of the tested solutions even when infused to very sick patients such as trauma victims with immediate risk of death from hypovolemia, hemodynamic instability and severe associated lesions. Studies performed in patients undergoing cardiovascular surgeries and in those who are critically ill in intensive care units provide data regarding the effects of hypertonic saline solutions in subjects with associated pre-existing diseases and with limited organ reserve, situations which are seldom seen in young trauma victims.

Questions raised from clinical trials have been addressed by experimental studies using clinically relevant large ani- 
mal models, particularly addressing concerns and perspectives with the use of hypertonic solutions for uncontrolled hemorrhage and head trauma.

\section{EFFICACY}

The ultimate test of efficacy for treatment of trauma with shock is enhanced survival, followed by other important endpoints such as reduced occurrence of multiple organ dysfunctions and of long-term disabilities. A number of reports have demonstrated significantly increased efficacy in patients treated with hypertonic saline followed by standard-of-care crystalloid infusion, when compared to equivalent patients receiving standard-of-care.

In the first performed trial, by Younes et al, 105 patients in hypovolemic shock patients treated in our institution with hypertonic saline showed a significant initial improvement of arterial pressure and reduced intravenous fluid requirements. No significant difference in mortality was detected. ${ }^{70}$ In a subsequent study in which 212 hypotensive patients were enrolled, the same group showed that hypertonic saline as initial treatment caused a significant decrease in long-term mortality rate for the subpopulation with an entry mean arterial pressure below $70 \mathrm{~mm} \mathrm{Hg} .{ }^{752}$

The largest controlled trial so far performed, the USA multicenter trial enrolled 422 patients. ${ }^{75} \mathrm{~A}$ significant increase in survival for the HSD treated patients in the subpopulation requiring surgery was shown. It also showed a greater incidence of adult respiratory distress syndrome, renal failure and coagulopathy in the standard-of-care alone treatment group. An extensive evaluation of coagulation profile and detailed laboratory workout demonstrated safety of HSD in this severely injured population. ${ }^{75}$

Hypotensive patients sustaining head injury with Glasgow Coma Scale scores of 8 or less which received hypertonic saline treatment presented higher survival to hospital discharge. This was demonstrated in a multicenter trial 77 as well as in a meta-analysis of individual patients from all the known clinical trials. ${ }^{44}$ A meta-analysis conducted on the individual patient records from controlled clinical studies on trauma demonstrated a significant increase in survival favoring HSD versus standard of care. ${ }^{78}$

\section{SAFETY AND CONTROVERSIES}

Bleeding. Since hypertonic saline resuscitation induces an immediate restoration of both cardiac output and arterial pressure, vasodilatation and hemodilution, several investigators raised concerns that these effects could overcome homeostatic mechanisms, such as vasoconstriction and local tamponade, and even hypotension. The solutions would therefore represent a potential risk for increased internal bleeding in humans, ${ }^{79,80}$ as shown in a series of experimental models of uncontrolled hemorrhage in rats, ${ }^{81-85}$ and pigs. ${ }^{86}$

These concerns were highlighted by the very controversial study which challenged the guidelines recommended by the Advanced Trauma Life Support Course, ${ }^{87}$ for the resuscitation of penetrating trauma victims and hypotension with large volumes of isotonic crystalloid solutions. ${ }^{88}$ This study suggested that standard-of-care pre-hospital and emergency room fluid infusion for these patients resulted in higher mortality and morbidity than what was observed for patients in whom delayed fluid resuscitation, i.e. after operative bleeding control. ${ }^{88}$ Unfortunately, the study is marred by a number of unresolved flaws.

On the other hand, the USA Multicenter Trial which compared standard-of-care fluid infusion to HSD followed by standard-of-care in the pre-hospital treatment of posttraumatic hypotension demonstrated that penetrating trauma victims with hypotension that received HSD presented higher arterial blood pressure and trends toward higher survival and less complications, when compared to standard-of-care fluid treatment alone. ${ }^{74}$ Similar results were observed by a meta-analysis of posttraumatic hypotension treated by hypertonic saline as the first fluid infused followed by standard of care treatment. ${ }^{78}$ Based on these data, we could speculate that the negative effects of large volume infusion of crystalloid solutions are not related solely to increased arterial pressure but to factors related to the isotonic solution itself. A trial comparing standard-of-care, HSD and delayed resuscitation would be needed to establish the best means to treat posttraumatic hypotension. Such a trial, conducted on sick human patients would however be open to severe ethical criticism.

While such a trial remains problematic, we have performed two studies comparing intra-abdominal blood loss measured 20 minutes after the beginning of small volume hypertonic saline bolus ( $4 \mathrm{~mL} / \mathrm{Kg} 7.5 \% \mathrm{NaCl}$ in $5 \mathrm{~min}$ ), large volume lactated Ringer's (32 mL/kg in $15 \mathrm{~min}$ ) or delayed resuscitation (no fluids). When administered, treatment was infused after 20 minutes of uncontrolled hemorrhage simulating a penetrating (Figure 4, iliac artery tear) ${ }^{89}$ or a blunt abdominal injury (Figure 5, splenic rupture $)^{90}$. In both experimental models, untreated controls remained in severe hypotension and low blood flows. Blood loss was not significantly increased by either treatment, suggesting that the hemodynamic benefits observed with fluid treatment were not associated with increased bleeding, which was directly measured after 40 minutes of uncontrolled bleeding. Our experimental data support observations of no increase in blood loss or blood product require- 
ment after HS or HSD in every human trauma trial of posttraumatic hypotension. In most experimental studies showing increased blood loss and mortality, fluid infusion was started immediately after the induction of uncontrolled hemorrhage, a scenario which is extremely uncommon following civilian and military trauma. ${ }^{81-84,86}$

Moreover, patients receiving hypertonic solutions in these posttraumatic hypotension studies underwent extensive laboratorial investigation, which showed that the coagulation profile was not altered by the amount of dextran 70 in the HSD formulation. Additionally, none of the studies with trauma victims or those trials to test the intraoperative use
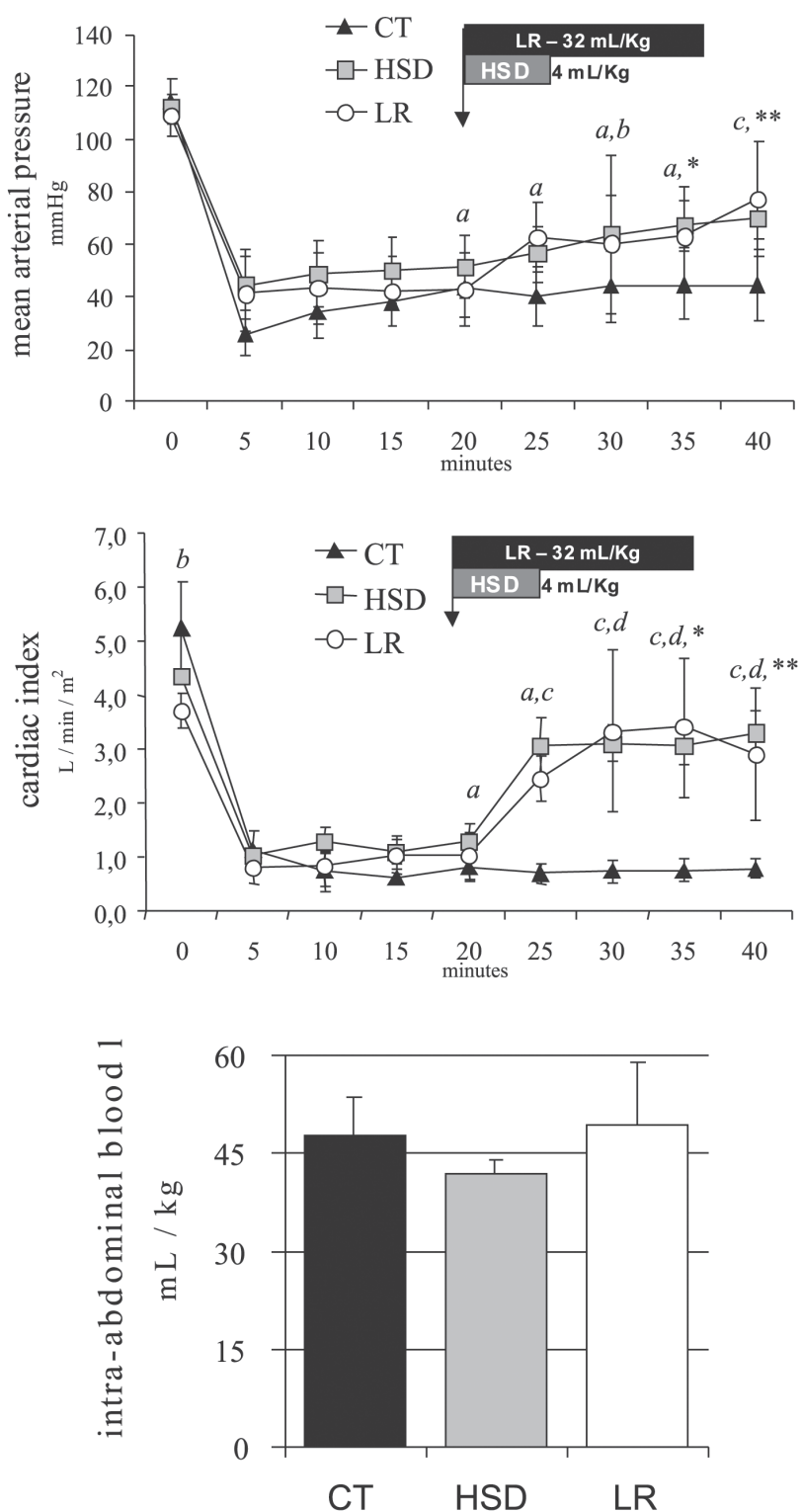

Figure 4 - Mean arterial pressure, cardiac index and blood volume loss during 40 minutes of uncontrolled intra-abdominal hemorrhage from an iliac artery tear for the CT group (no fluids), HSD group (4 $\mathrm{mL} / \mathrm{kg}$ over $5 \mathrm{~min})$, and the LR group $(32 \mathrm{~mL} / \mathrm{kg}$ over $15 \mathrm{~min}$ ). Adapted from Bruscagin et al, 2002. ${ }^{89}$ of HSD demonstrated any association between hypertonic solutions and blood loss or with increased requirements of blood products. In all studies so far performed, blood product requirements have always been associated with the severity and mechanism of injury, and not to the solution used. In fact, a reduction in subsequent fluid requirements is a common finding after the use of HSD. ${ }^{78}$

The use of HSD during complex cardiovascular surgeries, in which hemostasis alterations are common, ${ }^{91}$ was not associated with increased blood loss or increased blood product requirements. On the other hand, the use hypertonic solutions in cardiac and aortic surgeries has been frequently associated with hemodynamic stability and less, rather than more postoperative fluid requirements. ${ }^{92-95}$
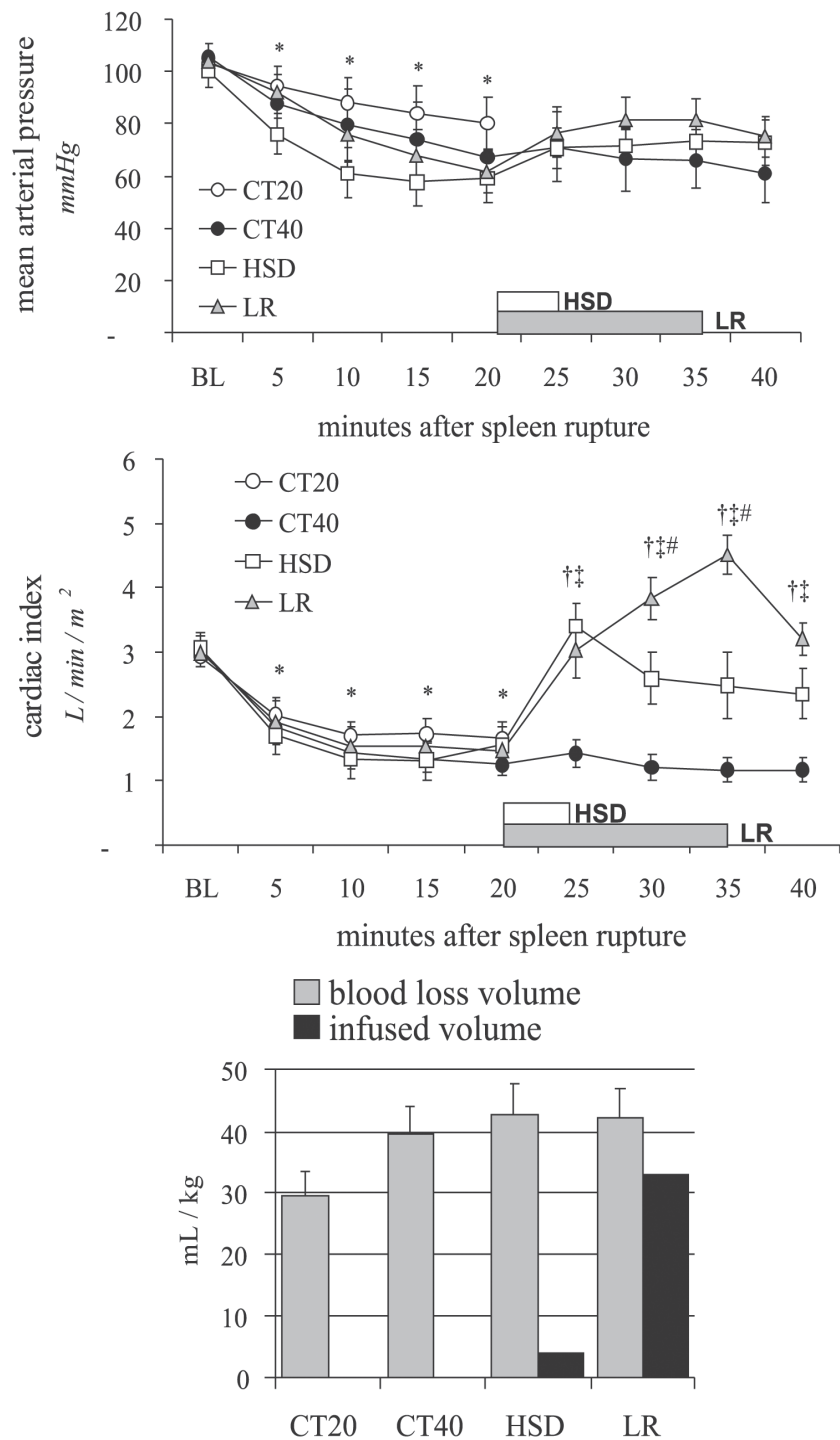

Figure 5 - Mean arterial pressure, cardiac index and blood volume loss during 40 minutes of uncontrolled intra-abdominal hemorrhage from a splenic rupture for the CT20 group (no fluids, $20 \mathrm{~min}$ ), CT40 (no fluids, $40 \mathrm{~min}$ ); HSD group ( $4 \mathrm{~mL} / \mathrm{kg}$ over $5 \mathrm{~min}$ ), and the LR group $(32 \mathrm{~mL} / \mathrm{kg}$ over $15 \mathrm{~min})$. Adapted from Varicoda et al, 2003. ${ }^{90}$ 
Overall, the common observation of less fluid requirements, no increase in blood products requirements, and trends toward less morbidity and mortality with the use of hypertonic solutions suggest that there is no increase in bleeding associated with its use, even in patients sustaining penetrating trauma or during complex cardiovascular surgeries.

Hypernatremia and neurological dysfunction. A frequent concern with hypertonic resuscitation is that it might possibly induce significant hypernatremia with potentially deleterious consequences. Such hypernatremia would of course result from cellular dehydration produced by the osmotic mechanisms already described. In severe hypernatremia, evidence of cellular dehydration is manifest much earlier in the central nervous system than in other organs or systems. Symptoms of hypernatremia include lethargy, tremors, weakness, irritability, delirium, mental confusion, seizures, coma and death. They occur in severe cases and, particularly, in small children and in the elderly.

The use of hypertonic sodium solutions to rapidly correct hyponatremia in patients with severe malnutrition or alcoholism may result in central pontine myelinolysis, which is manifest through dysartria, paraparesis or paraplegia. ${ }^{96}$ Another described complication with hypertonic sodium solutions for the correction of hyponatremia in neonates is the rupture of cerebral veins and intracranial hemorrhage, caused by the retraction of the cerebral tissue. ${ }^{97}$

With these questions in the forefront of all clinical trials, patients receiving $7.5 \% \mathrm{NaCl}$ were carefully evaluated for signs and symptoms of hypernatremia, particularly for the associated neurological alterations. This was especially true for patients at highest risk for neurological dysfunction and intracranial hypertension, i.e. those sustaining head trauma and systemic hypotension.

Despite the fact that moderate hypernatremia and hyperosmolarity have been detected in the overwhelming majority of patients receiving $7.5 \% \mathrm{NaCl}$ solutions, there was not a single case, among more than 1700 patients, of seizures, intracranial bleeding or neurological deterioration induced by the hypertonic solution. ${ }^{44,78}$ Necropsies and careful anatomicpathological studies of the brain tissues were performed in trauma victims, and produced no evidence of central pontine desmyelinization or of focal intracranial bleeding which could be attributed to the use of $7.5 \% \mathrm{NaCl} .{ }^{44,78}$

The short duration of the moderate hypernatremia, the absence of pre-existing hyponatremia, the exclusion of children and patients with chronic disabling diseases may have contributed to the lack of hypernatremia-related undesirable effects. On the other hand, hypotensive patients with head trauma and low Glasgow Coma Scale were one of the subgroups that most benefited from $7.5 \% \mathrm{NaCl}$ solutions as the initial treatment, presenting better neurological outcome and a significant increase in survival. ${ }^{44}$ Thus, $7.5 \%$ $\mathrm{NaCl}$-induced hypernatremia and hyperosmolarity were actually associated with neurological benefits, not with neurological dysfunction.

The well demonstrated findings that hypertonic saline induces favorable effects on both systemic hemodynamics and intracranial pressure in laboratory and clinical settings have stimulated a number of studies. In Figure 6, we show that in hemorrhaged dogs sustaining a unilateral cryogenic cerebral lesion, a small volume hypertonic saline bolus (4 $\mathrm{mL} / \mathrm{Kg} 7.5 \% \mathrm{NaCl}$ in $5 \mathrm{~min}$ ) reduced intracranial pressure. Mean arterial pressure was greater after large volume lactated Ringer's (32 mL/kg in $15 \mathrm{~min}$ ), but increased intracranial pressure was also observed Both treated groups showed similar improvement in cerebral perfusion pressure. No fluid infusion was associated with worse cerebral and systemic hemodynamics and greater increase in intraneural calcium at the penumbra area. ${ }^{98}$

Existing preliminary evidence supports the need for controlled clinical trials evaluating hypertonic saline use as resuscitative fluid in brain-injured patients with hemorrhagic shock, as therapy for intracranial hypertension resistant to standard therapy, as first line therapy for intracranial hypertension in certain intracranial pathologies, as small volume fluid resuscitation during spinal shock, and as maintenance intravenous fluid in neurocritical care units. ${ }^{99,100}$ Bolus infusions of $7.5 \% \mathrm{NaCl}$ or even of $23 \% \mathrm{NaCl}$ were the only means to achieve sustained control of intracranial hypertension after every other known measure failed. ${ }^{101}$

Although we cannot exclude that higher doses of hypertonic saline might induce hypernatremia-related side effects, it is also true that the prescribed dose cannot result in such effects. However, it does seem prudent to avoid these solutions for patients with the highest risk for severe neurological disturbances induced by hypernatremia, i.e. patients with chronic debilitating diseases and children.

Cardiac dysfunction. Experiments with anesthetized animals in shock have shown that a rapid injection of 7.5 $\mathrm{NaCl}$ may cause hypotension and arrhythmia, caused by hypertonicity-induced vasodilatation and reduction in peripheral vascular resistance. ${ }^{102}$ These events may be particularly dangerous when the arterial pressure is very low before the infusion of the solution. This hemodynamic instability is directly dependent on the speed with which the solution is being infused and may be avoided with infusion times greater than two minutes.

The majority of trials with intraoperative use of $7.5 \%$ $\mathrm{NaCl}$ has demonstrated physiologic benefits and no sideeffects. $^{92-95}$ There is however one study in patients with myo- 

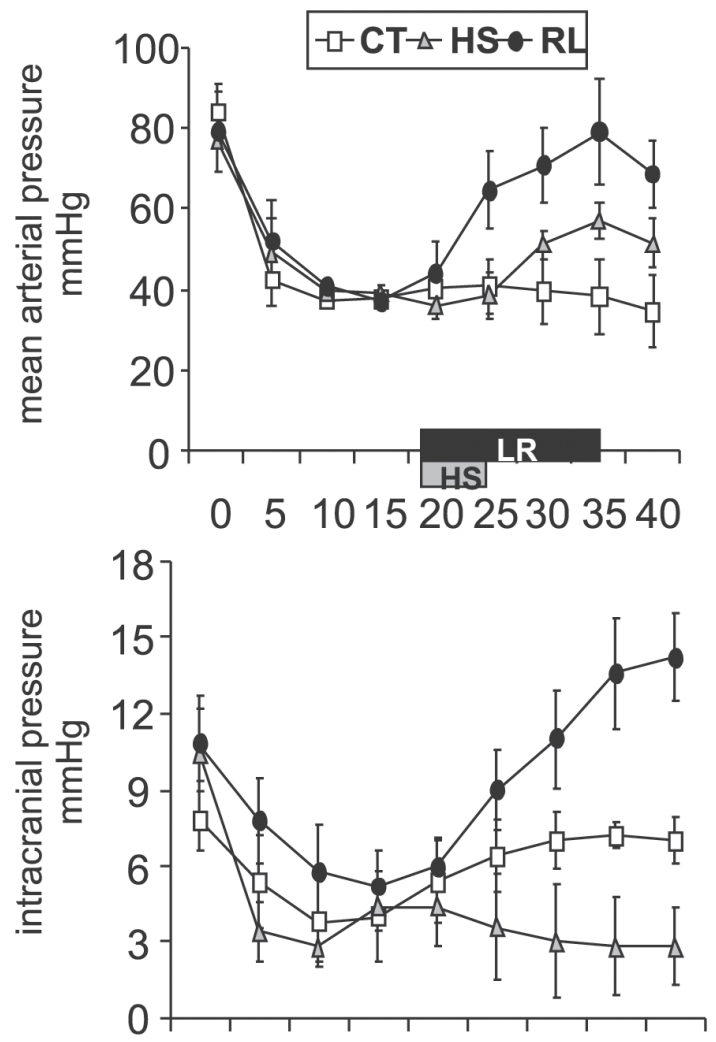

$0 \quad 510152025303540$
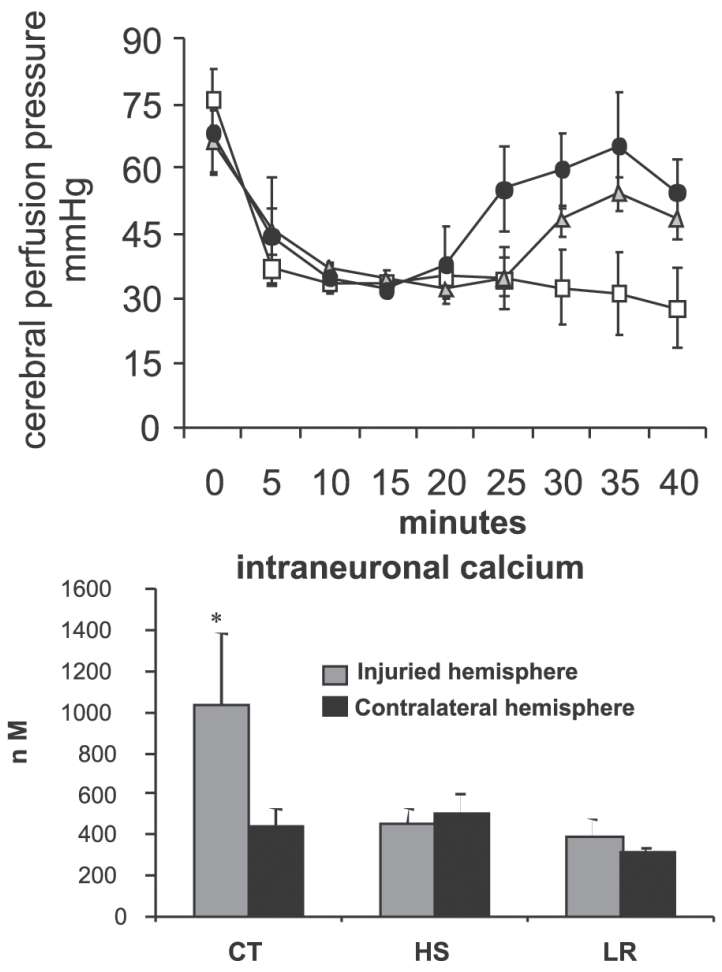

Figure 6 - Mean arterial, intracranial and cerebral perfusion pressures in hemorrhaged dogs sustaining an unilateral cerebral cryogenic lesion for the CT group (no fluids), HSD group (4 $\mathrm{mL} / \mathrm{kg}$ over $5 \mathrm{~min}$ ), and the LR group ( $32 \mathrm{~mL} / \mathrm{kg}$ over $15 \mathrm{~min}$ ). Intraneural calcium measured from cerebral byopsies from the penumbra area and contralateral hemisphere. Adapted from Balbino, 2001. ${ }^{98}$ cardial dysfunction undergoing coronary artery bypass in which pre-operative volume expansion with $250 \mathrm{~mL}$ of HSS caused hypotension and transient left ventricular failure. ${ }^{103}$ This study showed that $7.5 \% \mathrm{NaCl}$ solutions can be deleterious if rapidly infused in patients with ventricular dysfunction. ${ }^{104}$ In a similar study, in patients with cardiac dysfunction, in which the volume of $7.5 \% \mathrm{NaCl}$ solution was titrated to a target cardiac filling pressure, it was found that a lower dosage was enough to achieve the desired hemodynamic profile, with no hemodynamic instability. ${ }^{104}$

In a separate study, a fixed dose of HSD $(250 \mathrm{~mL})$ was used during extracorporeal circulation in Jehovah's witness, with no hemodynamic changes and reduced fluid requirements in the postoperative period. ${ }^{95} \mathrm{~A}$ similar dose was used in surgical procedures for correction of thoracic and abdominal aortic aneurysms. ${ }^{92,93,105}$ These procedures are normally associated with sudden hemodynamic changes, marked fluid loss to the third space and high incidence of postoperative complications. ${ }^{106}$ The use of hypertonic saline solutions resulted in hemodynamic stability and fluid sparing in the postoperative period in these procedures.

The use of $7.5 \% \mathrm{NaCl}$ solution to patients with cardiogenic shock after right ventricular infarction also produced sustained hemodynamic benefits. ${ }^{107}$

When the whole population of 1700 patients in which $7.5 \% \mathrm{NaCl}$ solutions were used is examined, there were no cases of cardiac death. However, it seems prudent to recommend caution with the use of hypertonic solutions in patients with heart diseases. Rigorous monitoring is mandatory and gradual and slower infusions should be employed. The safety profile for the use of $7.5 \% \mathrm{NaCl}$ solutions in children was recently established by Rocha e Silva et al. during the surgical correction of congenital cardiac defects. ${ }^{108}$

Hyperchloremic acidosis. Hypertonic $\mathrm{NaCl}(7.5 \%)$ solutions induce a significant increase in chloride plasma levels, and this could predispose to hyperchloremic acidosis. Clinically relevant acidosis was observed in trauma victims that were moribund on arrival and the acidosis was associated with pre-existing conditions such as cardiac arrest or severe hypothermia. ${ }^{72}$ Despite hemodynamic and metabolic improvement after $7.5 \% \mathrm{NaCl}$ solutions in the majority of patients, it is reasonable to suggest, based on the clinical evidence, that these solutions should be avoided in patients with preexisting severe acidosis, especially when such acidosis follows cardiac arrest or prolonged pre-hospital times.

\section{CONCLUSION}

Based on the available clinical experience with 7.5\% $\mathrm{NaCl}$ solutions, we conclude that the use of hypertonic solutions is safe, but it is prudent to avoid their use for a 
well defined patient population, i.e. moribund, or chronic debilitating diseases. Although safety in children undergoing elective cardiac surgery has been demonstrated, additional studies under other disease conditions are warranted. Efficacy has been suggested for this procedure as the first treatment for posttraumatic hypotension, particularly for penetrating trauma victims requiring surgery and for those sustaining head trauma. Elective intraoperative use of these solutions has been associated with hemodynamic stability and fluid sparing. However, in patients with cardiac failure, titrated dosage and careful moni- toring are required. Increased bleeding, clinically significant hypernatremia and allergic reactions were not associated with hypertonic resuscitation. Hypertonic solutions are commercially available and have been used in several European countries. A large USA trial is been designed to obtain approval by the FDA. Although the safety issue has been well established, it does appear that a larger prospective, multicenter trials is required to better define the patient population to maximally benefit from hypertonic saline solutions.

\section{RESUMO}

ROCHA-E-SILVA e col. Soluções hipertônicas para reanimação de pacientes em choque. CLINICS 60(2): 159-172, 2005

O uso de soluções hipertônicas para reanimação de pacientes em choque é um conceito relativamente novo. Baseou-se originalmente na idéia de que uma expansão volêmica significativa podia ser obtida às custas de um volume relativamente diminuto de infusão, aproveitando a propriedade física de osmose. Logo ficou claro que a capacidade fisiológica de produzir vasodilatação, compartilhada por todas as soluções hipertônicas, seria valiosa para reperfundir territórios tornados isquêmicos pelo choque, embora os malefícios da sequiência isquemia - reperfusão devessem ser considerados. Pesquisa subseqüente revelou propriedades antes insuspeitadas da reanimação hipertônica. Verificou-se que este procedimento revertia instantanea- mente o edema endotelial e de hemácias, com importantes consequiências em termos de circulação capilar. Mais recentemente, um conjunto de efeitos da hipertonicidade sobre o sistema imune vem sendo estudado, mas as possíveis implicações destas descobertas em relação ao cenário clínico ainda suscitam discussão. As soluções hipertônicas estão em uso em algumas partes do mundo, apesar de objeções levantadas contra tal uso, em virtude de dados experimentais derivados de experimentos de hemorragia não controlada. Tais objeções não parecem se justificar em face dos resultados obtidos numa série de ensaios clínicos e no uso corrente destas soluções. Esta revisão procura cobrir um pouco da história, remota e recente, deste campo do conhecimento.

UNITERMOS: Tratamento de choque. Hemorragia. Soluções hipertônicas. Circulação imune.

\section{REFERENCES}

1. Penfield, WG. The treatment of severe and progressive hemorrhage by intravenous injections. Am J Physiol, 1919; $48: 121-8$.

2. Silbert S. The treatment of thromboangeitis obliterans by intravenous injection of hypertonic solutions: Preliminary report. Jama, 1926; 86: 1759.

3. Baue AE, Tragus ET, Parkins WM. A comparison of isotonic and hypertonic solutions and blood on blood flow and oxygen consumption in the initial treatment of hemorrhagic shock. J Trauma. 1967; 7:743-56

4. Baue AE, Tragus ET, Parkins WM. Effects of sodium chloride and bicarbonate in shock with metabolic acidosis. Am J Physiol. 1967; 212: 54-60.

5. Messmer K, Mokry G, Jesch F.The protective effect of hypertonic solutions in shock. Br J Surg. 1969;56(8):626.
6. Gazitua S, Scott JB, Chou CC, Haddy FJ. Effect of osmolarity on canine renal vascular resistance. Am J Physiol. 1969; 217:121623.

7. Velasco IT, Pontieri V, Rocha e Silva M, Lopes OU. Hyperosmotic $\mathrm{NaCl}$ and severe hemorrhagic shock. Am J Physiol 1980; 239:H664-73 .

8. Fellippe JJ de, Timoner J, Velasco IT, Lopes OU, Rocha e Silva M. Treatment of refractory hypovolaemic shock by $7.5 \%$ sodium chloride injections. Lancet 1980; ii:1002-4.

9. Kramer GC, Elgjo GI, Poli de Figueiredo LF, Wade C. Hyperosmotic-hypertonic solutions. Clinical Anesthesiology 1997;11:143-61.

10. Nakayama S, Sibley L, Gunther R, Holcroft JW, Kramer GC. Small volume resuscitation with hypertonic saline resuscitation (2400 mosm/l] during hemorrhagic shock. Circ Shock 1984; 13:149-59. 
11. Smith GJ, Kramer GC, Perron P, Nakayama S, Gunther RA, Holcroft JW. A comparison of several hypertonic solutions for resuscitation of bled sheep. J Surg Res 1985; 39:517-28.

12. Kramer GC, Perron PR, Lindsey DC, Ho HS, Gunther RA, Boyle WA et al. Small-volume resuscitation with hypertonic saline dextran solution. Surgery 1986; 100:239-47.

13. Poli de Figueiredo LF, Peres CA, Attalah AN, Romaldini H, Miranda F Jr, Francisco J, et al. Hemodynamic improvement in hemorrhagic shock by aortic balloon occlusion and hypertonic saline solutions. Cardiovasc Surg 1995; 3:679-86.

14. Rocha-e-Silva M, Negraes GA, Soares AM, Pontieri V, Loppnow L. Hypertonic resuscitation from severe hemorrhagic shock: patterns of regional circulation. Circ Shock 1986; 19:165-75.

15. Rocha e Silva M. Evolving concepts in small volume resuscitation: the experimental basis. In: Kreimeier U, Christ F, Messmer K, editors. Small-volume hyperosmolar volume resuscitation. Heidelberg: Springer-Verlag, 1999.

16. Velasco IT, Rocha e Silva M, Oliveira MA, Oliveira MA, Silva RI. Hypertonic and hyperoncotic resuscitation from severe hemorrhagic shock in dogs: A comparative study. Crit Care Med 1989;17:261-4.

17. Kramer GC, Elgjo GI, Poli de Figueiredo LF. Hyperosmotichyperoncotic solutions. Balliéres Clinical Anaesthesiology 1997;11:143-61.

18. Matteucci MJ, Wisner DH, Gunther RA, Wooley DE. Effects of hypertonic and isotonic fluid infusion on the flash evoked potential in rats: hemorrhage, resuscitation, and hypernatremia. J Trauma 1993;34:1-7.

19. Kreimeier U, Bruckner U, Niemczyk S, Messmer K. Hyperosmotic saline dextran for resuscitation from traumatic-hemorrhagic hypotension: Effect on regional blood flow. Circ Shock 1990; 32:83-99.

20. Rocha e Silva M, Velasco IT, Nogueira da Silva RI, Oliveira MA, Negraes GA, Oliveira MA. Hyperosmotic sodium salts reverse severe hemorrhagic shock: other solutes do not. Am J Physiol 1987; 253:H751-62.

21. Horton JW, Walker PB Small-volume hypertonic saline dextran resuscitation from canine endotoxin shock. Ann Surg 1991; 214-64-73

22. Moon PF, Kramer GC Hypertonic saline-dextran resuscitation from hemorrhagic shock induces transient mixed acidosis. Crit Care Med. 1995;23:323-31.

23. Cox AT, Ho HS, Gunther RA High level of arginine vasopressin and $7.5 \% \mathrm{NaCl} / 6 \%$ dextran-70 solution: cardiovascular and renal effects. Shock. 1994 1:372-6.

24. Mazzoni MC, Borgstrom P, Arfors KE, Intaglietta M. Dynamic fluid redistribution in hyperosmotic resuscitation of hypovolemic hemorrhage. Am J Physiol. 1988; 255: H62937.

25. Mazzoni M, Borgstron P, Intaglietta M, Arfors KE. Capillary narrowing in hemorrhagic shock is rectified by hyperosmotic saline-dextran reinfusion. Circ Shock 1990; 31:407-18.
26. Border JR, Hassett J, LaDuca J, Seibel R, Steinberg S, Mills B et al. The gut origins septic states in blunt multiple trauma (ISS=40) in the ICU. Ann Surg 1987; 206:427-48.

27. Carrico CJ, Meakins JL, Marshall JC, Fry D, Mayer RV. Multiple organ failure syndrome. Arch Surg 1986;121:196-208.

28. Deitch EA, Bridges W, Berg R, Specian RD, Granger DN. Hemorrhagic shock-induced bacterial translocation: the role of neutrophils and hydroxyl radicals. J Trauma 1990;942-52.

29. Mullins RJ, Hudgens RW. Hypertonic saline resuscitates dogs in endotoxin shock. J Surg Res 1987;43: 37-44.

30. Armistead CW Jr, Vincent JL, Preiser JC, De Backer D, Thuc Le Minh. Hypertonic saline solution-hetastarch for fluid resuscitation in experimental septic shock. Anesth Analg 1989; 69:714-20

31. Kreimeier U, Frey L, Dentz J, Herbel T, Messmer K. Hypertonic saline dextran resuscitation during the initial phase of acute endotoxemia: effect on regional blood flow. Crit Care Med $1991 ; 19: 801-9$

32. Crystal GJ, Gurevicius J, Kim SJ, Eckel PK, Ismail EF, Salem MR. Effects of hypertonic saline solutions in the coronary circulation. Circ Shock 1994; 42:27-38

33. Maningas P. Resuscitation with $7.5 \% \mathrm{NaCl}$ in $6 \%$ dextran-70 during hemorrhagic shock in swine: effects on organ blood flow. Crit Care Med 1987; 15:1121-6.

34. Kreimeier U, Bruckner U, Schmidt J, Messmer K. Instantaneous restoration of regional organ blood flow after severe hemorrhage: effect of small-volume resuscitation with hypertonic-hyperoncotic solution. J Surg Res 1990; 49:493503

35. Ing RD, Nazeeri MN, Zeldes S, Dulchavsky SA, Diebel LN. Hypertonic saline/dextran improves septic myocardial performance. Am Surg 1994; 60:507-8.

36. Kien ND, Kramer GC. Cardiac performance following hypertonic saline. Braz J Med Biol Res 1989; 22:2245-8.

37. Goertz AW, Mehl T, Lindner KH, Rockemann MG, Schirmer U, Schwilk B et al. Effect of $7.2 \%$ hypertonic saline $/ 6 \%$ hetastarch on left ventricular contractility in anesthetized humans. Anesthesiology 1995; 82:1389-95.

38. Welte M, Goresch T, Frey L, Holzer K, Zwissler B, Messmer K. Hypertonic saline dextran does not increase cardiac contractile function during small volume resuscitation from hemorrhagic shock in anesthetized pigs. Anesth Analg 1995; 80:1099-207.

39. Constable PD, Muir WW, Binkley PF. Hypertonic saline is negative inotropic agent in normovolemic dogs. Am J Physiol 1994; 267:H667-77.

40. Sondeen JL, Gonzaludo GA, Loveday JA, Rodkey WG, Wade CE. Hypertonic saline/dextran improves renal function after hemorrhage in conscious swine. Resuscitation 1990;20:23141 .

41. Prough DS, Johnson JC, Poole GV Jr, Stullken EH, Johnston WE $\mathrm{Jr}$, Royster R. Effects on intracranial pressure of resuscitation from hemorrhagic shock with hypertonic saline versus lactated Ringer's solution. Crit Care Med 1985;13:407-11. 
42. Prough DS, Johnson JC, Stump DA, Stullken EH, Poole GV Jr, Howard G. Effects of hypertonic saline versus lactated Ringer's solution on cerebral oxygen transport during resuscitation from hemorrhagic shock. J Neurosurg 1986;64:627-32.

43. Walsh JC, Zhuang J, Shackford SR. A comparison of hypertonic to isotonic fluid in the resuscitation of brain injury and hemorrhagic shock. J Surg Res 1991;50:284-7.

44. Wade CE, Grady JJ, Kramer GC, Younes RN, Gehlsen K, Holcroft JW. Individual cohort analysis of the efficacy of hypertonic saline/dextran in patients with traumatic brain injury and hypotension. J Trauma 1997; 42:S61-5.

45. Bayer M, Nolte D, Lehr HA, Messmer K. Hypertonic-hyperoncotic dextran solution reduces post-ischemic leukocyte adherence in post-capillary vessels. Langenbecks Arch Chir 1991; [suppl $1]: 375-8$.

46. Coimbra R, Junger WG, Hoyt DB. Immunosuppression following hemorrhage is reduced by hypertonic saline resuscitation. Surg. Forum 1995; 46:84-7.

47. Coimbra R, Junger WG, Liu FC. Loomis WH, Hoyt DB. Hypertonic/hyperoncotic fluids reverse prostaglandin E2 (PGE2) induced T-cell suppression. Shock 1995; 3:45-9.

48. Coimbra R, Junger WG, Hoyt DB, Liu FC, Loomis WH, Evers MF. Hypertonic saline resuscitation restores hemorrhageinduced immunosuppression by decreasing prostaglandin E2 and interleukin-4 production. J Surg Res 1996; 64:203-9.

49. Coimbra R, Hoyt DB, Junger WG, Angle N, Wolf P, Loomis W et al. Hypertonic Saline resuscitation decreases susceptibility to sepsis after hemorrhagic shock. J Trauma 1997; 42:602-7.

50. Deitch EA, Shi HP, Feketeova E, Hauser CJ, Xu DZ. Hypertonic saline resuscitation limits neutrophil activation after traumahemorrhagic shock. Shock. 2003;19:328-33.

51. Yada-Langui MM, Coimbra R, Lancellotti C, Mimica I, Garcia C, Correia N Jr, Rocha e Silva M. Hypertonic saline and pentoxifylline prevent lung injury and bacterial translocation after hemorrhagic shock. Shock. 2000;14:594-8.

52. Pascual JL, Ferri LE, Seely AJ, Campisi G, Chaudhury P, Giannias B, Evans DC, et al. Hypertonic saline resuscitation of hemorrhagic shock diminishes neutrophil rolling and adherence to endothelium and reduces in vivo vascular leakage. Ann Surg. 2002;236:634-42.

53. Yada-Langui MM, Anjos-Valotta EA, Sannomiya P, Rocha e Silva M, Coimbra R Resuscitation affects microcirculatory polymorphonuclear leukocyte behavior after hemorrhagic shock: role of hypertonic saline and pentoxifylline. Exp Biol Med 2004;229:684-93.

54. Ciesla DJ, Moore EE, Gonzalez RJ, Biffl WL, Silliman CC. Hypertonic saline inhibits neutrophil (PMN) priming via attenuation of p38 MAPK signaling. Shock. 2000;14:265-9.

55. Powers KA, Zurawska J, Szaszi K, Khadaroo RG, Kapus A, Rotstein OD Hypertonic resuscitation of hemorrhagic shock prevents alveolar macrophage activation by preventing systemic oxidative stress due to gut ischemia/reperfusion.. Surgery. 2005;137:66-74.
56. Chen H, Inocencio R, Alam HB, Rhee P, Koustova E. Differential expression of extracellular matrix remodeling genes in rat model of hemorrhagic shock and resuscitation. J Surg Res. $2005 ; 123: 235-44$.

57. Murao Y, Hata M, Ohnishi K, Okuchi K, Nakajima Y, Hiasa Y, Junger WG, Hoyt DB, Ohnishi T. Hypertonic saline resuscitation reduces apoptosis and tissue damage of the small intestine in a mouse model of hemorrhagic shock. Shock. 2003;20:23-8.

58. Parreira JG, Rasslan S, Poli de Figueiredo LF, Bortolheiro TC, Sinosaki S, Hardt D, Yada Langui M, Rocha MN, Longui CA, Chiattone C, Rocha e Silva M. Impact of shock and fluid resuscitation on the morphology and apoptosis of bone marrow: An experimental study. J Trauma 2004;56:1001-8.

59. Hotchkiss RS, Karl IE. The pathophysiology and treatment of sepsis. N Engl J Med. 2003;348:138-50

60. Chen H, Inocencio R, Alam HB, Rhee P, Koustova E. Differentia expression of extracellular matrix remodeling genes in rat model of hemorrhagic shock and resuscitation. J Surg Res. 2005;123:235-44.

61. Junger WG, Coimbra R, Liu FC, Herdon-Remelius C, Junger W, Junger $\mathrm{H}$ et al. Hypertonic saline resuscitation. A tool to modulate immune function in trauma patients. Shock 1997; $8: 235-41$

62. Wade CE. Hypertonic saline resuscitation in sepsis. Crit Care. 2002;6:418-23

63. Oliveira RP, Velasco I, Soriano F, Friedman G. Clinical review: Hypertonic saline resuscitation in sepsis. Crit Care. 2002;6:397-

64. Kolsen-Petersen JA. Immune effect of hypertonic saline: fact or fiction? Acta Anaesthesiol Scand. 2004;48:667-78

65. Poli de Figueiredo LF, Mathru M, Solanki D, Macdonald VW, Hess J, Kramer GC. Pulmonary hypertension and systemic vasoconstriction may offset the benefits of acellular hemoglobin blood substitutes. J Trauma1997; 42:847-54.

66. Poli de Figueiredo LF, Nelson SH, Mathru M, e Silva MR, Kramer GC. Effects of hemoglobin-based blood substitutes on vasoactivity of rat aortic rings. Artif Organs. 2001;25:928-33.

67. Poli de Figueiredo LF, Elgjo GI, Mathru M, Rocha e Silva M, Kramer GC. Hypertonic acetate-alpha-alpha-hemoglobin for small volume resuscitation of hemorrhagic shock. Artif Cells Blood Subs Immob Biotech 1997; 25:61-73.

68. Poli de Figueiredo LF, Mathru M, Jones J. Inhaled nitric oxide reverses cell-free hemoglobin-induced pulmonary hypertension and decreased lung compliance. Preliminary results. Crit Care 1997; 1:111-6.

69. Rabinovici R, Rudolph AS, Vernick J, Feuerstein G: A new salutary resuscitative fluid: liposome encapsulated hemoglobin/ hypertonic saline solution. J Trauma 1993; 35:121-6.

70. Younes RN, Aun F, Accioly CQ, Casale LP, Szajnbok I, Birolini D. Hypertonic solutions in the treatment of hypovolemic shock: A prospective, randomized study in patients admitted to the emergency room. Surgery 1992; 111:380-5. 
71. Maningas PA, Mattox KL, Pepe PE, Jones RL, Feliciano DV, Burch JM. Hypertonic saline-dextran solutions for the prehospital management of traumatic hypotension. Am Surg 1989; 157:528-34

72. Vassar MJ, Perry CA, Holcroft JW. Analysis of potential risks associated with $7.5 \%$ sodium chloride resuscitation of traumatic shock. Arch Surg 1990; 125:1309-15.

73. Vassar MJ, Perry CA, Gannaway WL, Holcroft JW. 7.5\% sodium chloride/dextran for resuscitation of trauma patients undergoing helicopter transport. Arch Surg 1991;126:1065-72.

74. Mattox KL, Maningas PA, Moore EE, Mateer JR, Marx JA, Aprahamian $\mathrm{C}$ et al. Prehospital hypertonic saline/dextran infusion for post-traumatic hypotension - The USA multicenter trial. Ann Surg 1991; 213:482-91.

75. Younes RN, Aun F, Ching CT, Goldenberg DC, Franco MH, Miura FK et al. Prognostic factors to predict outcome following the administration of hypertonic/hyperoncotic solution in hypovolemic patients. Shock 1997; 7:79-83.

76. Vassar MJ, Perry CA, Holcroft JW. Prehospital resuscitation of hypotensive trauma patients with $7.5 \% \mathrm{NaCl}$ versus $7.5 \% \mathrm{NaC}$ with added dextran: a controlled trial. J Trauma 1993; 34:622 32

77. Vassar MJ, Fisher RP, O'Brien PE, Bachulis BR, Chambers JA, Hoyt DB et al. A multicentre trial for resuscitation of injured patients with $7.5 \%$ sodium chloride. The multicenter group for the study of hypertonic saline in trauma patients. Arch Surg 1993; 128:1003-11.

78. Wade CE, Kramer GC, Grady JJ, Fabian TC, Younes RN. Efficacy of hypertonic $7.5 \%$ saline and $6 \%$ dextran-70 in treating trauma: a meta-analysis of controlled clinical studies. Surgery $1997 ; 122: 609-16$

79. Krausz MM, Bar-Ziv M, Rabinovici R, Gross D. "Scoop and run" or stabilize hemorrhagic shock with normal saline or small-volume hypertonic saline? J Trauma. 1992;33:6-10.

80. Krausz MM. Controversies in shock research: hypertonic resuscitation-pros and cons. Shock 1995;3:69-72

81. Gross D, Landau EH, Assalia A, Krausz MM. Is hypertonic saline resuscitation safe in "uncontrolled" hemorrhagic shock? J Trauma 1988; 28:751-6.

82. Gross D, Landau EH, Klin B, Krausz MM. Quantitative measurement of bleeding following hypertonic saline therapy in 'uncontrolled' hemorrhagic shock. J Trauma 1989;29:7983

83. Krausz MM, David M, Amstislavsky T. Hypertonic saline treatment of hemorrhagic shock in awake rats. Shock $1994 ; 2: 267-70$

84. Krausz MM, Landau EH, Klin B, Gross D. Hypertonic saline treatment of uncontrolled hemorrhagic shock at different periods from bleeding. Arch Surg 1992;127:93-6

85. Rabinovici R, Krausz MM, Feuerstein G. Control of bleeding is essential for a successful treatment of hemorrhagic shock with 7.5 per cent sodium chloride solution. Surg Gynecol Obstet 1991;173:98-106.
86. Bickell WH, Bruttig SP, Wade CE. Hemodynamic responses to abdominal aortotomy in the anesthetized swine. Circ Shock $1989 ; 28: 321-32$.

87. American College of Surgeons, Committee on Trauma. Advanced Trauma Life Support Program for Physicians, fifth edition. Chicago: American College of Surgeons, 1993.

88. Bickell WH, Wall MJ, Pepe PE, Martin RR, Ginger VF, Allen MK et al. Immediate versus delayed fluid resuscitation for hypotensive patients with penetrating torso injuries. N Engl J Med 1994; 331:1105-9.

89. Bruscagin V, Poli de Figueiredo LF, Rasslan S, Varicoda EY, M Rocha e Silva. Fluid resuscitation improves hemodynamics without increased bleeding in a model of uncontrolled hemorrhage induced by an iliac artery tear. J Trauma 2002;52:1147-52

90. Varicoda EY, Poli de Figueiredo LF, Silva LE, Rocha e Silva M. Blood loss after fluid resuscitation with isotonic or hypertonic saline for the treatment of uncontrolled hemorrhage induced by spleen rupture. J Trauma 2003;55:112-7

91. Poli de Figueiredo LF, Coselli JS. Individual strategies of hemostasis for thoracic aortic surgery. J Card Surg 1997; $12: 222-8$.

92. Younes RN, Bechara MJ, Langer B, Aun F, Birolini D, Kuzniek S et al. Use of a hypertonic solution of $7.5 \% \mathrm{NaCl}$ in preventing post-declamping hypotension of the abdominal aorta. Rev Ass Med Brasil 1987; 34:150-4.

93. Auler JOC, Pereira MH, Gomide-Amaral RV, Stolf NG, Jatene AD, Rocha e Silva M. Hemodynamic effects of hypertonic sodium chloride during surgical treatment of aortic aneurysms. Surgery 1987 ; 101:594-601.

94. Boldt J, Zickmann B, Ballesteros M, Herold C, Dapper F, Hempelmann G. Cardiorespiratory responses to hypertonic saline solution in cardiac operations. Ann Thorac Surg 1991; 51:610-5.

95. Oliveira SA, Bueno RM, Souza JM Senra DF, Rocha e Silva M. Effects of hypertonic saline dextran on the postoperative evolution of Jehovah's Witness patients submitted to cardiac surgery with cardiopulmonary bypass. Shock 1995; 3:391-4.

96. Sterns RH, Riggs JE, Schochet SS Jr. Osmotic demyelination syndrome following rapid correction of hyponatremia. N Engl J Med 1986; 314:1535-41.

97. Finberg L, Luttrell E, Redd H. Pathogenesis of lesions in the nervous system in hypernatremic states: II. Experimental studies of gross anatomic changes and alterations of chemical composition of the tissues. Pediatrics 1959; 23:46-66.

98. Balbino M. Initial treatment of head trauma and hemorrhagic shock: comparison between hypertonic saline solution and lactated Ringer's on the blockage of increased intraneural calcium. Doctoral thesis, Dept Surgery, University of São Paulo School of Medicine, 2001

99. Qureshi AI,Suarez JI. Use of hypertonic saline solutions in treatment of cerebral edema and intracranial hypertension. Crit Care Med 2000; 28:3301-3313

100. Rocha e Silva M. Hypertonic/hyperoncotic treatment for brain damage. Crit Care Med 2003;31:2559-60. 
101. Suarez JI, Qureshi AI, Bhardwaj A. Treatment of refractory intracranial hypertension with $23.4 \%$ saline. Crit Care Med 1998; 26:1118-22

102. Kien ND, Kramer GC, White DA. Acute hypotension caused by rapid saline infusion in anesthetized dogs. Anesth Analg 1991; 73:597-602.

103. Prien T, Thulig B, Wusten R Schoofs J, Weyand M, Lawin P. Hypertonic-hyperoncotic volume replacement $(7.5 \% \mathrm{NaCl} /$ $10 \%$ hydroxyethyl starch $200.000 / 0.5$ ) in patients with coronary artery stenoses Zentralbl Chir 1993; 118:257-66.

104. Ellinger K, Fahnle M, Schroth M, Albrecht DM Optimal preoperative titrated dosage of hypertonic-hyperoncotic solutions in cardiac risk patients. Shock 1995;3:167-72.

105. Christ F, Niklas M, Kreimeier U, Lauterjung L, Peter K, Messmer K. Hyperosmotic-hyperoncotic solutions during abdominal aortic aneurysm (AAA) resection. Acta Anaesthesiol Scand 1997; 41:62-70.
106. Coselli JS, Poli de Figueiredo LF, LaMarie SA. Impact of a previous thoracic aneurysm repair on the management of thoracoabdominal aortic aneurysm. Ann Thorac Surg 1997; 64:639-50.

107. Ramires JAF, Serrano CV, César LAM, Velasco IT, Rocha e Silva M Pilleggi F. Acute hemodynamic effects of hypertonic (7.5\%) saline infusion in patients with cardiogenic shock due to right ventricular infarction. Circ Shock 1992;37:220-5.

108. Rocha e Silva R, Caneo LF, Lourenco Filho DD, Jatene MB, Barbero-Marcial M, Oliveira SA, Rocha-E-Silva M. First use of hypertonic saline dextran in children: a study in safety and effectiveness for atrial septal defect surgery. Shock. 2003;20:427-30. 